\title{
A Cytotoxic Saponin from Albizia julibrissin
}

\author{
Kun Zou, ${ }^{*, a, b}$ Yu-Ying ZHAO, ${ }^{b}$ and Ru-Yi ZHANG ${ }^{b}$ \\ ${ }^{a}$ Hubei Key Laboratory of Natural Product Research and Development, Chemistry and Life Science College, China Three \\ Gorges University; Yichang 443002, P.R. China: and ${ }^{b}$ School of Pharmaceutical Sciences, Peking University; Beijing \\ 100083, P.R. China. Received February 19, 2006; accepted April 12, 2006
}

\begin{abstract}
A new triterpenoidal saponin (1: Julibroside $J_{21}$ ) with a xylopyranosyl moiety located at its $C-21$ side chain was isolated from Albizia julibrissin Durazz. (Leguminosae), and its structure was determined on the basis of comprehensive spectroscopic analyses. Compound 1 showed marked inhibitory action against Bel-7402 cancer cell line at $10 \mu \mathrm{g} / \mathrm{ml}$.
\end{abstract}

Key words Albizia julibrissin; Julibroside $\mathrm{J}_{21}$; cytotoxicity; Leguminosae

The stem bark of Albizia julibrissin DuRAzz. (Leguminosae) is recorded in the Chinese Pharmacopoeia as a sedative and anti-inflammatory agent, and specified to treat injuries from falls and remove carbuncles. ${ }^{1)}$ In the preceding studies, ${ }^{2-4)}$ we reported the isolation and structure elucidation of some complicated and cytotoxic julibrosides from the stem bark of this plant. Recently, Haridas et al., ${ }^{5-7)}$ have reported the anti-cancer actions of avicins, a family of triterpenoid saponins obtained from the Australian desert tree Acacia victoriae (Leguminosae: Mimosoideae). Avicins showed strong inhibitory action towards human cancer cells and inducing action to cell apoptosis, partly via perturbing mitochondrial function. Their experiments also showed that avicins prevented chemical-induced carcinogenesis in mice, and strongly inhibited TNF-induced NF-kappa B. This paper reports the isolation and structure elucidation of compound $\mathbf{1}$, an analogue of Julibroside $\mathrm{J}_{1}(\mathbf{2})$. Compound $\mathbf{1}$ showed significant cytotoxic activity against the Bel-7402 cancer cell line by the SRB (Sulforhodamine B) method. ${ }^{8)}$

The $95 \%$ ethanol extract from stem barks of A. julibrissin was suspended over water and extracted successively with $\mathrm{CHCl}_{3}$, EtOAc and $n-\mathrm{BuOH}$, respectively. The $n-\mathrm{BuOH}$ soluble part was chromatographed on $\mathrm{D}_{101}$ macroporous resins and silica gels, giving rise to colorless powders (Frs. 4143). A tridesmodic saponin (1) was obtained from Frs. 4143 by Sephadex LH-20, $\mathrm{C}_{18}$ silica gel column chromatography and preparative HPLC.

Compound 1, a white powder, gave a positive Liebermann-Burchard reaction. The FAB-MS mass spectrum ((Fast Atom Bombardment Mass Spectroscopy, positive ion) of 1 gave the quasi-molecular ion peak at $m / z 2182[\mathrm{M}+\mathrm{K}+1]^{+}$ and $2167[\mathrm{M}+\mathrm{Na}+2]^{+}$, which was indicative of the formula $\mathrm{C}_{100} \mathrm{H}_{158} \mathrm{O}_{49}$. The ${ }^{1} \mathrm{H}-\mathrm{NMR}$ spectrum showed seven angular methyl signals at $\delta 1.28,1.00,0.96,1.15,1.86,1.04,1.06$ (each $3 \mathrm{H}, \mathrm{s}$ ) and sugar proton signals at $\delta 3.4-6.3$. The data suggested a triterpenoid saponin. On acidic hydrolysis, 1 furnished the aglycone which was identical with an authentic sample, acacic acid lactone on high-performance thin layer chromatography, and on PC the resulting sugars were identified as glucose, xylose, rhamnose, arabinose and quinovose. The ${ }^{13} \mathrm{C}$-NMR spectrum gave nine anomeric carbon signals at $\delta 95.6,99.2,100.1,101.7,102.2,105.7,106.2,106.7$ and 111.1. The corresponding anomeric proton signals at $\delta 4.87$ $(1 \mathrm{H}, \mathrm{d}, J=7.4 \mathrm{~Hz}, \mathrm{H}-\mathrm{glc}-1), 5.14$ (1H, br s, H-arap-1), 4.98 $(1 \mathrm{H}, \mathrm{d}, J=6.3 \mathrm{~Hz}, \mathrm{H}-\mathrm{xyl}-1), 6.03\left(1 \mathrm{H}, \mathrm{d}, J=7.6 \mathrm{~Hz}, \mathrm{H}-\mathrm{glc}^{\prime}-\right.$
1), $5.88(1 \mathrm{H}, \mathrm{s}, \mathrm{H}-\mathrm{rha}-1), 6.24(1 \mathrm{H}, \mathrm{s}, \mathrm{H}-\mathrm{araf}-1), 5.31(1 \mathrm{H}, \mathrm{d}$, $\left.J=7.9 \mathrm{~Hz}, \mathrm{H}-\mathrm{glc}^{\prime \prime}-1\right), 4.82(1 \mathrm{H}, \mathrm{d}, J=7.6 \mathrm{~Hz}, \mathrm{H}-q u i-1), 4.80$ $\left(1 \mathrm{H}, \mathrm{d}, J=7.5 \mathrm{~Hz}, \mathrm{H}-\mathrm{xyl}^{\prime}-1\right)$ were assigned according to HMQC (Heteronuclear Multiple Quantum Coherence) results. Based on the ${ }^{1} \mathrm{H}$ - and ${ }^{13} \mathrm{C}-\mathrm{NMR}$ data of $\mathbf{1}$, the anomeric configurations in the sugar moieties were determined as $\beta$ configuration for glucose, xylose, and quinovose moieties, and $\alpha$-configuration for rhamnose and arabinose moieties. ${ }^{9}$ Except for the resonances of protons and carbons belonging to aglycone and sugar moieties, two groups of proton and carbon-13 signals due to monoterpenoids (MT, $\mathrm{MT}^{\prime}$ ) were observed in the ${ }^{1} \mathrm{H}$ - and ${ }^{13} \mathrm{C}$-NMR spectra of $\mathbf{1}$ (see Experimental).

It was deduced by a careful comparison of the carbon-13 data of 1 with those of $\mathbf{2}$ that the signals of the aglycone, monoterpene and sugars moieties of $\mathbf{1}$ were almost superimposable on those of $\mathbf{2}$, except that signals of $\mathbf{2}$ due to a quinovose moiety were different from those of $\mathbf{1}$ due to a sugar moiety. The correlation between an anomeric carbon13 signal at $\delta 100.1$ and an anomeric proton signal at $\delta 4.80$ was observed in the HMQC spectrum of $\mathbf{1}$. A marked spin coupling system was observed among proton signals at $\delta$ $4.80,4.24,4.19,4.11,3.95$ and 3.66 in the TOCSY (Total Correlation Spectroscopy) spectrum of 1. Corresponding to the above proton signals, five carbon-13 signals at $\delta 100.1$, 75.4, 78.6, 70.8 and 66.9 were observed in the ${ }^{13} \mathrm{C}$-NMR

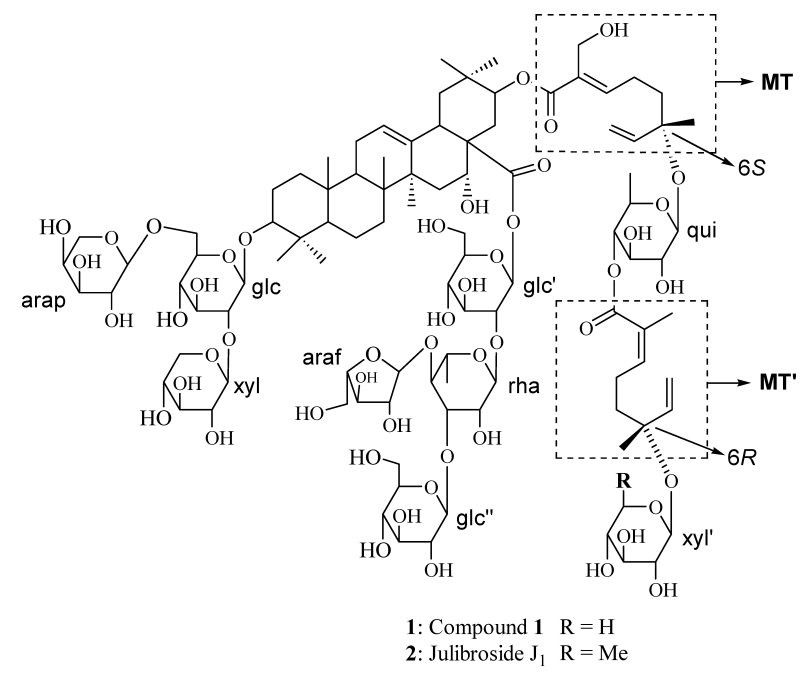

Fig. 1. The Structures of Compound $\mathbf{1}$ and Julibroside $\mathrm{J}_{1}$ (2) 
spectra of $\mathbf{1}$, and their correlation peaks were observed in the HMQC spectrum of 1 , which suggested a xylopyranosyl moiety in $1{ }^{10)}$ The correlation between the proton signal at $\delta$ 4.82 due to the anomeric proton of $\beta$-D-quinovopyranosyl moiety and the carbon-13 signal at $\delta 79.7$ due to the C-6 of the inner MT moiety was observed in the HMBC (Heteronuclear Multiple-Bond Correlation) spectrum of 1, which determined the linkage of $\beta$-D-quinovopyranosyl moiety to the inner MT moiety at C-21 side chain. Meanwhile, the correlation between the proton signal at $\delta 4.80$ due to the anomeric proton of $\beta$-D-xylopyranosyl moiety and the carbon-13 signal

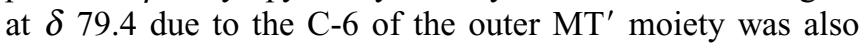
observed in the HMBC spectrum of 1 , which suggested that the xylopyranosyl moiety be the terminal residue of C-21 side chain. This linkage mode was further conformed by its FAB-MS results (see Experimental).

Therefore, the structure of 1 was identified as $3-O-[\beta$-Dxylopyranosyl- $(1 \rightarrow 2)-\alpha$-L-arabinopyranosyl- $(1 \rightarrow 6)-\beta$-D-glucopyranosyl]-21-O-\{(6S)-2-trans-2-hydroxymethyl-6methyl-6-O-[4-O-(6R)-2-trans-2,6-dimethyl-6- $O-(\beta$-D-xylopyranosyl-2,7-octadienoyl)]- $\beta$-D-quinovopyranosyl-2,7-octadienoyl $\}$ acacic acid 28- $O$ - $\beta$-D-glucopyranosyl- $(1 \rightarrow 3)-[\alpha-$ L-arabinofuranosyl- $(1 \rightarrow 4)]$ - $\alpha$-L-rhamnopyranosyl- $(1 \rightarrow 2)-\beta$ D-glucopyranosyl ester, named as Julibroside $\mathrm{J}_{21}$ (see Fig. 1).

Compound 1 showed marked inhibitory action against Bel-7402 cells (human liver cancer cell line) (inhibition $80.8 \%)$ at $10 \mu \mathrm{g} / \mathrm{ml}$ in SRB method.

\section{Experimental}

Optical rotation was recorded with a Perkin-Elmer 241 spectropolarimeter. IR spectrum was measured on a Perkin-Elmer 983 FTIR instrument as samples in pressed $\mathrm{KBr}$ disks. 1D and 2D NMR spectra were recorded using Bruker AM 500 and Varian-300 instruments with $\mathrm{Me}_{4} \mathrm{Si}$ as the intestinal standard. FAB mass spectra were recorded using a ZABspec mass spectrometer. HPLC was carried out using (1) a Gilson automatic system for preparative HPLC with an Alltima $\mathrm{C}_{18}$ column $(5 \mu \mathrm{m}, 60 \AA$, pore size, $22 \times 250 \mathrm{~mm}$ i.d. and $10 \mu \mathrm{m}, 60 \AA, 22 \times 250 \mathrm{~mm}$ i.d.), or (2) Waters 600 semipreparative HPLC with a $\mu$ Bondpak $\mathrm{C}_{18}$ column $(6 \mu \mathrm{m}, 60 \AA, 7.8 \times 300 \mathrm{~mm}$ i.d.). Macroporous resin $\mathrm{D}_{101}$ (Nankai), Silica Gel $(10-40 \mu \mathrm{m}, 200-300$ mesh, Qingdao), Sephadex LH-20, RP C 18 Silica Gel (100-200 mesh) (Ouya, Pharmacia) were used as packing materials for column chromatography.

Plant Material Dried stem bark of A. julibrissin was purchased from Mianyang Medicinal Company of Sichuan Province in October 1995. A sample has been deposited in the Division of Natural Medicinal Chemistry of Perking University.

Extraction and Isolation Air-dried powdered stem bark $(13.5 \mathrm{~kg})$ was extracted with $95 \% \mathrm{EtOH}$. The EtOH residues $(1140 \mathrm{~g})$ were suspended in water, and then extracted with $\mathrm{CHCl}_{3}$, EtOAc and $n-\mathrm{BuOH}$, respectively. The $n$ - $\mathrm{BuOH}$-soluble extract was dissolved in $\mathrm{MeOH}$, and then poured dropwise into acetone. The resulting precipitate was chromatographed over a $D_{101}$ resin column with gradient elution $(100 \%$ water $\rightarrow 100 \% \mathrm{MeOH})$. The fraction from the $\mathrm{MeOH}$ elution ( $248 \mathrm{~g}$ ) was subjected to silica gel column chromatography using a gradient solvent system of $\mathrm{CHCl}_{3}-\mathrm{MeOH}$-water $(100: 0: 0 \rightarrow 6: 4: 1)$ to afford 68 fractions $(500 \mathrm{ml} /$ fraction). Frs. $41-43$ was decolorized by activated charcoal in $\mathrm{MeOH}$ to give a white powder $(22.5 \mathrm{~g})$. The white powder $(10.5 \mathrm{~g})$ was subjected to repeated Sephadex LH20 , silica gel, RP $\mathrm{C}_{18}$ silica gel column chromatography, and preparative HPLC (43:57 MeCN-water, $8.0 \mathrm{ml} / \mathrm{min}, 216 \mathrm{~nm}$ detection) to afford 1 (64.8 mg).

Bioassay The cytotoxic activity of $\mathbf{1}$ was evaluated according to the same protocol as the literature. ${ }^{8)}$

Acid Hydrolysis This experiment was carried out according to the procedure described in literature. ${ }^{2)}$
Julibroside $\mathrm{J}_{21}(\mathbf{1})$ : Amorphous white powder, $[\alpha]_{\mathrm{D}}^{25}-28^{\circ}(c=0.25$, $\mathrm{MeOH}$ ). FAB-MS (positive mode) $\mathrm{m} / \mathrm{z}: 2182[\mathrm{M}+\mathrm{K}+1]^{+}, 2167$ $[\mathrm{M}+\mathrm{Na}+2]^{+}, 2035[\mathrm{M}+\mathrm{Na}+2-\mathrm{xyl}]^{+}, 1845\left[\mathrm{M}+\mathrm{Na}+2-\left(\mathrm{xyl}+\mathrm{MT}^{\prime}\right)\right]^{+}$, $1564[\mathrm{M}+\mathrm{Na}+2-(2 \mathrm{glc}+\text { rha }+ \text { ara })]^{+}, \quad 1380 \quad\left[\mathrm{M}+\mathrm{Na}-\left(\mathrm{xy}+\mathrm{MT}^{\prime}+\right.\right.$ qui + $\mathrm{MT})-\mathrm{glc}]^{+}$. IR (KBr) $v_{\max } \mathrm{cm}^{-1}: 3410,2927,1692,1640,1383,1281$, $1074 \mathrm{~cm}^{-1} .{ }^{1} \mathrm{H}-\mathrm{NMR}\left(500 \mathrm{MHz}\right.$, pyridine- $\left.d_{5}\right) \delta: 1.28,1.00,0.96,1.15,1.86$, $1.04,1.06(3 \mathrm{H} \times 7, \mathrm{~s}, \mathrm{H}-23,24,25,26,27,29,30), 5.61(1 \mathrm{H}, \mathrm{br} \mathrm{s}, \mathrm{H}-12)$, $4.87(1 \mathrm{H}, \mathrm{d}, J=7.4 \mathrm{~Hz}, \mathrm{H}-\mathrm{glc}-1), 5.14(1 \mathrm{H}$, br s, H-arap-1), $4.98(1 \mathrm{H}, \mathrm{d}$, $J=6.3 \mathrm{~Hz}, \mathrm{H}-\mathrm{xyl}-1), 6.03\left(1 \mathrm{H}, \mathrm{d}, J=7.6 \mathrm{~Hz}, \mathrm{H}-\mathrm{glc}^{\prime}-1\right), 5.88(1 \mathrm{H}, \mathrm{s}, \mathrm{H}-\mathrm{rha}-1)$, $6.24\left(1 \mathrm{H}, \mathrm{s}, \mathrm{H}\right.$-araf-1), $5.31\left(1 \mathrm{H}, \mathrm{d}, J=7.9 \mathrm{~Hz}, \mathrm{H}-\mathrm{glc}^{\prime \prime}-1\right), 4.82(1 \mathrm{H}, \mathrm{d}$, $J=7.6 \mathrm{~Hz}, \mathrm{H}-q u i-1), 4.80\left(1 \mathrm{H}, \mathrm{d}, J=7.5 \mathrm{~Hz}, \mathrm{H}-x^{\prime} \mathrm{l}^{\prime}-1\right), 1.75(3 \mathrm{H}, \mathrm{d}$, $J=5.5 \mathrm{~Hz}, \mathrm{H}-$ rha-6), $1.33(3 \mathrm{H}, \mathrm{d}, J=6.1 \mathrm{~Hz}, \mathrm{H}$-qui-6), $7.02(1 \mathrm{H}, \mathrm{t}, J=7.0 \mathrm{~Hz}$, H-MT-3), 2.64 (2H, m, H-MT-4), $1.71(2 \mathrm{H}, \mathrm{m}, \mathrm{H}-\mathrm{MT}-5), 6.17(1 \mathrm{H}, \mathrm{dd}$, $J=8.9,18.3 \mathrm{~Hz}, \mathrm{H}-\mathrm{MT}-7), 5.19(1 \mathrm{H}, \mathrm{d}, J=8.9 \mathrm{~Hz}, \mathrm{H}-\mathrm{MT}-8 \mathrm{a}), 5.44(1 \mathrm{H}, \mathrm{d}$, $J=18.3 \mathrm{~Hz}$, H-MT-8b), 4.71 (2H, s, H-MT-9), 1.49 (3H, s, H-MT-10), 7.05 $\left(1 \mathrm{H}, \mathrm{t}, J=7.2 \mathrm{~Hz}, \mathrm{H}_{-} \mathrm{MT}^{\prime}-3\right), 2.47$ (2H, m, H-MT'-4), $1.81\left(2 \mathrm{H}, \mathrm{m}, \mathrm{H}-\mathrm{MT}^{\prime}-\right.$ 5), $6.30\left(1 \mathrm{H}, J=11.1,17.5 \mathrm{~Hz}, \mathrm{H}_{-} \mathrm{MT}^{\prime}-7\right), 5.18\left(1 \mathrm{H}, \mathrm{d}, J=11.1 \mathrm{~Hz}, \mathrm{H}_{-} \mathrm{MT}^{\prime}-\right.$ 8a), $5.31\left(1 \mathrm{H}, \mathrm{d}, J=17.5 \mathrm{~Hz}, \mathrm{H}-\mathrm{MT}^{\prime}-8 \mathrm{~b}\right), 1.92\left(3 \mathrm{H}, \mathrm{s}, \mathrm{H}_{-} \mathrm{MT}^{\prime}-9\right), 1.46(3 \mathrm{H}$, s, H-MT'-10). ${ }^{13} \mathrm{C}-\mathrm{NMR}\left(125 \mathrm{MHz}\right.$, pyridine- $\left.d_{5}\right) \delta: 39.6(\mathrm{C}-1), 26.9(\mathrm{C}-2)$ 88.7 (C-3), 40.1 (C-4), 56.0 (C-5), 18.4 (C-6), 33.6 (C-7), 40.4 (C-8), 47.1 (C-9), 37.1 (C-10), 23.7 (C-11), 123.1 (C-12), 143.3 (C-13), 42.0 (C-14), 35.9 (C-15), 73.8 (C-16), 51.6 (C-17), 40.9 (C-18), 47.9 (C-19), 35.4 (C-20), 77.0 (C-21), 36.4 (C-22), 28.2 (C-23), 17.1 (C-24), 15.8 (C-25), 17.3 (C-26), 27.2 (C-27), 174.5 (C-28), 29.2 (C-29), 19.1 (C-30), 106.7 (C-glc-1), 76.8 (C-glc-2), 78.4 (C-glc-3), 72.6 (C-glc-4), 77.2 (C-glc-5), 69.5 (C-glc-6), 102.2 (C-arap-1), 80.3 (C-arap-2), 72.5 (C-arap-3), 67.4 (C-arap-4), 64.2 (Carap-5), 106.2 (C-xyl-1), 75.6 (C-xyl-2), 77.8 (C-xyl-3), 70.8 (C-xyl-4), 67.2 (C-xyl-5), 95.6 (C-glc'-1), 76.8 (C-glc'-2), 78.1 (C-glc'-3), 71.2 (C-glc'-4), 79.0 (C-glc'-5), 62.0 (C-glc'-6), 101.7 (C-rha-1), 70.5 (C-rha-2), 82.0 (Crha-3), 78.9 (C-rha-4), 69.1 (C-rha-5), 18.8 (C-rha-6), 111.1 (C-araf-1), 84.4 (C-araf-2), 78.4 (C-araf-3), 85.4 (C-araf-4), 62.5 (C-araf-5), 105.7 (C-glc"1), 75.3 (C-glc"-2), 78.4 (C-glc"-3), 71.8 (C-glc"-4), 78.4 (C-glc"-5), 62.8 (C-glc"-6), 99.2 (C-qui-1), 75.4 (C-qui-2), 78.4 (C-qui-3), 76.8 (C-qui-4), 73.0 (C-qui-5), 18.6 (C-qui-6), 100.1 (C-xyl'-1), 75.4 (C-xyl'-2), 78.6 (C$\left.\mathrm{xyl}^{\prime}-3\right), 70.8$ (C-xyl'-4), 66.9 (C-xyl'-5), 167.5 (C-MT-1), 133.8 (C-MT-2), 145.2 (C-MT-3), 23.5 (C-MT-4), 40.9 (C-MT-5), 79.7 (C-MT-6), 143.9 (CMT-7), 115.0 (C-MT-8), 56.3 (C-MT-9), 23.9 (C-MT-10), 167.8 (C-MT'-1), 127.6 (C-MT'-2), 143.7 (C-MT'-3), 23.6 (C-MT'-4), 38.5 (C-MT'-5), 79.4 (C-MT'-6), 144.3 (C-MT'-7), 114.3 (C-MT'-8), 12.6 (C-MT'-9), 24.6 (C$\left.\mathrm{MT}^{\prime}-10\right)$.

Acknowledgements This research was financially supported by a gran (code: 29632050) from the National Natural Science Foundation of China. The NMR spectra were provided by Beijing Institute of Microchemistry.

\section{References}

1) The Pharmacopoeia Committee of People's Republic of China (ed.), "Pharmacopoeia (I)," People Health Press, Beijing, 1995, pp. 119120.

2) Zou K., Tong W. Y., Liang H., Cui J. R., Tu G. Z., Zhao Y. Y., Zhang R. Y., Carbohydr. Res., 340, 1329-1334 (2005).

3) Zou K., Zhao Y. Y., Tu G. Z., Zhang R. Y., Jia Z. H., Carbohydr. Res., 324/3, 182-188 (2000).

4) Zou K., Cui J. R., Wang B., Zhao. Y. Y., Zhang R. Y., J. Asian Nat. Prod. Res., 7, 783-788 (2005).

5) Haridas V., Higuchi M., Jayatilake G. S., Bailey K. M., Blake M. E., Arntzen C. J., Gutterman J. U., Proc. Natl. Acad. Sci. U.S.A., 98, $5821-5825$ (2001).

6) Hanausek M., Ganesh P., Wasaszek Z., Arntzen C. J., Slaga T. J., Proc. Natl. Acad. Sci. U.S.A., 98, 11551-11556 (2001).

7) Haridas V., Arntzen C. J., Gutterman J. U., Proc. Natl. Acad. Sci. U.S.A., 98, 11557-11562 (2001).

8) Skehan P., Storeng R., Scudiero D., Monks A., McMahon J., Vistica D., Warren J. T., Bokesch H., Kenney S., Boyd M. R., J. Natl. Cancer Institute, 82, 1107-1109 (1990).

9) Agrawal P. K., Phytochemistry, 31, 3307-3330 (1992).

10) Kiuchi F., Gafur M. A., Obata T., Tachibana A., Tsuda Y., Chem. Pharm. Bull., 45, 807-812 (1997). 